\title{
Social Media Motivations Scale (SMM-S): Measure Adaptation and Predictors
}

\section{Escala de Motivaciones de Redes Sociales (SMM-S): adaptación de medida y predictores}

\author{
Pâmela Fardin Pedruzzi ${ }^{\mathrm{a}, *}$, Isabela Medeiros de Almeida ${ }^{\mathrm{a}}$, \\ Fabíola Rodrigues Matos ${ }^{\mathrm{a}}$, Alexsandro Luiz de Andrade ${ }^{\mathrm{a}}$ \\ ${ }^{a}$ Graduate Program in Psychology, Federal University of Espírito Santo, Brazil
}

\begin{abstract}
Background: The motivation for using social networks helps to understand the online behaviors of the adult population and can be an important predictor of several variables, considering their common usage on a daily routine. Objective: This article aimed to seek evidence of validity and reliability of the Social Media Motivations Scale (SMM-S) in the Brazilian context and understand its relationship with personality and life satisfaction. Method: The research was carried out in two stages, each consisting of 600 adults who were users of online social networks. The study subjects were mostly women with higher education who came from all Brazilian regions and selected Instagram as their favorite online service. Results: The results demonstrated the validity and reliability of a Brazilian version of the SMM-S. The items were preserved and the structure was organized into four dimensions: Freedom in Social Networks, Routine in Social Networks, Identity in Social Networks, and Social Maintenance. Correlations with life satisfaction and personality revealed evidence of convergent validity. Conclusion: The instrument showed psychometric evidence of validity in the Brazilian context. The article discusses the motivations for social network usage in different settings.
\end{abstract}

Keywords: Internet; Social Networks; Scale; Life Satisfaction; Personality.

Para citar este artículo:

Fardin, P., Medeiros, I., Rodrigues, F., \& Luiz, A. (2021). Social Media Motivations Scale (SMM-S): Measure Adaptation and Predictors. Liberabit, 27(2), e472. https://doi.org/10.24265/ liberabit.2021.v27n2.04

\section{Resumen}

Antecedentes: la motivación por el uso de las redes sociales ayuda a comprender los comportamientos en línea de la población adulta y puede ser un predictor relevante de varias variables, considerando su uso común en la vida cotidiana. Objetivo: este artículo tuvo como objetivo buscar evidencia de validez y confiabilidad para la Escala de Motivaciones de Redes Sociales (SMM-S, por sus siglas en inglés) en el contexto brasileño y comprender su relación con la personalidad y la satisfacción con la vida. Método: la investigación se realizó en dos etapas, con 600 adultos en cada una, usuarios de redes sociales en línea. En ambas muestras, la mayoría eran mujeres con estudios superiores de todas las regiones brasileñas y señalaron a Instagram como su servicio en línea favorito. Resultados: los resultados arrojaron indicadores de validez y confiabilidad para la versión brasileña de la Escala de Motivaciones en Redes Sociales, los ítems fueron preservados y la estructura se organizó en cuatro dimensiones: libertad en redes sociales, rutina en redes sociales, identidad en redes sociales y mantenimiento social. Las correlaciones con la satisfacción con la vida y la personalidad revelaron evidencia de validez convergente. Conclusiones: el instrumento presentó evidencia psicométrica de validez para el contexto brasileño. El artículo presenta una discusión sobre las motivaciones para usar las redes sociales en diferentes contextos.

Palabras clave: internet; redes sociales; escala; satisfacción con la vida; personalidad.

Este es un artículo Open Access publicado bajo la licencia Creative Commons Atribución 4.0 Internacional. (CC-BY 4.0)

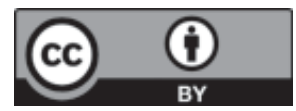

Universidad de San Martín de Porres, Lima - Perú http://ojs3.revistaliberabit.com 


\section{Introduction}

The advent of Internet popularization provided several changes in conceiving communication between people (Copetti \& Quiroga, 2018; Matias \& Matos, 2013). In recent years, the growth in Internet access in Brazil has demonstrated its relevance as a facilitator of relationships, communication, and as a tool for solving everyday tasks (Instituto Brasileiro de Geografia e Estatística [IBGE], 2018; Seabra et al., 2017).

In this context, one of the leading exponents of online communication is the social networking sites that favor sharing various elements between people, such as contacts and information (Patrício \& Gonçalves, 2010; Rosado et al., 2014). According to the Brazilian Internet Steering Committee (2019), one of the main online activities in Brazil is sending instant messages via WhatsApp, for example. From a social perspective on virtual social networks, it is possible to reflect the accessibility and reach of such communication. Individuals of different ages, social classes, and cultures can participate in this environment (Macedo, 2016; Krug et al., 2018).

Virtual social networks give individuals the possibility to create an online profile in which they can present themselves virtually, create connections with other individuals connected in the network, and thus enter even more in the navigation of these associations (Boyd \& Ellison, 2007; Celli et al., 2014; Uski \& Lampinen, 2016). Twitter, Facebook, and Instagram are some examples, with millions of users considering them services that aim to interact with people (Kumar \& Geethakumari, 2014; Lee et al., 2015; Recuero, 2012).

Personality traits (Durak \& Senol-Durak, 2014; Puerta-Cortés \& Carbonell, 2014; Wang et al., 2015), addictions (D’Arienzo et al., 2019), and romantic relationships (Flach \& Deslandes, 2017; Haack \& Falcke, 2017; Hobbs et al., 2017) are examples of investigative aspects considered by researchers concerning life on the Internet. In this way, individuals prefer specific contents that best meet their needs or motivations (Wang et al., 2015).

Individual characteristics, among which personality traits highlight (Puerta-Cortés \& Carbonell, 2014), are present when selecting the media of interest. Personality is important to predict Internet use and is associated with global use (Mark \& Ganzach, 2014) or problematic use (Durak \& Senol-Durak, 2014). The complex use of the Internet, which damages the individual's personal and professional life, has an association with neuroticism (positive) and conscientiousness (negative) (Durak \& Senol-Durak, 2014). Studies indicate that neuroticism is related to Internet dependency (Blackwell et al., 2017; BowdenGreen et al., 2021) and addiction (Matos et al., 2016; Samarein et al., 2013). However, sociability and extroversion are negatively associated with maladaptive behaviors (Servidio, 2014). Therefore, personality generally influences society's online choices and behavior (Arnoux et al., 2017; Azucar et al., 2018; Kircaburun et al., 2020).

The Internet also brought about several changes in the origin and maintenance of relationships, creating new environments for virtual interactions and relationship networks, such as developing friendships and romantic relationships (Flach \& Deslandes, 2017). Regarding the latter, Haack and Falcke (2017) describe those online services facilitate contact between partners. However, the success of a relationship depends on the person-to-person interaction, since it provides greater consistency, adding intimacy, commitment, passion, and satisfaction, thus reducing marital problems.

To evaluate the passive and active use of social networking sites (Wang et al., 2018), the problematic use of the Internet (Bothe et al., 2018; Pereira et al., 2020), and the use of social networking sites (Wang et al., 2015), psychometric scales and instruments were developed.

So far, the only scale aimed at evaluating the motivations for using social media is the Social Media 
Motivations Scale (SMM-S; Orchard et al., 2014), which was developed in the United Kingdom. It applies the Uses and Gratifications Theory (Katz et al., 1974) as a theoretical basis. This perspective describes that users choose their favorite online social networks based on personal goals and needs, which can be influenced by psychological and social aspects. Furthermore, the benefits and returns arising from using a particular online social network also affect this choice (Orchard et al., 2014). The SMM-S was structured with open questionnaires on the daily use of online social networks (quantity, time spent, preferred type), along with questions about the benefits of their service, and was measured using a Likert scale. Concerning the research methods, the number of items per dimension was generated using the principal component analysis (PCA), and the internal consistency of the factors was determined by Cronbach’s alpha.

In this way, to determine the main motivations for using online social networks is of paramount importance in the current setting since they are an important variable to understand the backgrounds and consequences of online behavior among the adult population. In this sense, the present study sought to adapt and raise evidence of the SMM-S (Orchard et al., 2014) in the Brazilian context. Additionally, this research aimed to a) understand the reasons for using social media on life satisfaction, and b) evaluate how personality traits, using the Big Five personality model (Hauck et al., 2012), are associated with the reasons for using online social networks.

\section{Method}

This study had a survey designed and was conducted in two stages. The first stage included the translation, adaptation, and evidence gathering of the internal structure, and attempted to replicate the British model based on confirmatory factor analysis (CFA) procedures. The second stage presented an alternative for the internal structure compared to the original model, using exploratory factor analysis (EFA) techniques (Hauck, 2019). In addition, the study presented the axiological network for the construct.

\section{Stage 1 Participants}

At the beginning of the research, 600 Brazilian adults joined the study. The inclusion criteria were being 18 years old or older and using at least one online social network. The sample consisted of individuals aged between 18 and $41(M=23.5$; $S D=2.94)$, 73.5\% of whom were women $(n=441)$. Regarding the marital status, most participants reported being single (85.8\%; $n=515)$. They came from all Brazilian regions: $62.8 \%$ $(n=377)$ were from the Southeast, $14.3 \%(n=86)$ from the South, $8.7 \%(n=52)$ from the Center-West, $7.2 \%(n=42)$ from the Northeast, and 5.3\% $(n=32)$ from the North; .2\% $(n=1)$ lived abroad; and 1.5\% $(n=9)$ did not respond to this inquiry. Their average income was from 1 to 3 minimum wages ( $\mathrm{R} \$ 998.00$ $-\mathrm{R} \$ 2,994.00)$. Concerning their education level, 570 individuals reported having an undergraduate degree (92.2\%), and having studied in public institutions ( $n=$ 368; $66.3 \%$ ), private institutions ( $n=138 ; 24.7 \%$ ) or both ( $n=25 ; 4.2 \%)$. One (1) person reported not having attended high school and 29 not having a college degree. Their favorite social networks were Instagram (23.2\%; $n=142)$, Twitter (8.7\%; $n=53)$, and Facebook $(3.5 \% ; n=22)$.

\section{Stage 2 Participants}

Six hundred (600) Brazilian adults took part in this stage of the research. The inclusion criteria remained the same as those mentioned in stage 1 . The sample consisted of individuals aged between 28 and 69 years $(M=39.46$; $S D=9.5)$, $73.16 \%$ of whom were women $(n=439)$. Regarding the marital status, 356 reported being married or in a stable relationship (59.3\%) and 206 being single (34.3\%). The participants came from the five Brazilian regions: $57.2 \%(n=343)$ were from the Southeast, $17.7 \%$ $(n=106)$ from the South, $11.8 \%(n=71)$ from the Center-West, 6\% $(n=36)$ from the North, and 5.5\% from the Northeast $(n=33) ; .5 \%(n=3)$ lived 
abroad; and $1.3 \%(n=8)$ did not respond to this inquiry. Their average income was from 3 to 6 minimum wages ( $\mathrm{R} \$ 2,994.00-\mathrm{R} \$ 5,988.00)$. Concerning their education level, only two (2) individuals did not attend high school, and 16 did not pursued undergraduate studies. The rest $(n=584)$ reported having an undergraduate degree or being currently in college, out of which 295 (49\%) studied in public institutions, 216 (36 \%) in private institutions and $73(12 \%)$ in both. Their favorite social networks were Instagram (18.3\%; $n=110)$, WhatsApp (9.5\%; $n=57)$, and Facebook (7.5\%; $n=45)$.

\section{Instrument's Adaptation Procedures}

The SMM-S (Orchard et al., 2014) is an instrument that aims to assess the motivations for using online social media and consists of 40 items (for example: «Because it's a good distraction from other things»). In its original version, it has ten (10) factors; namely, procrastination ( $\alpha=.89$ ), freedom of expression ( $\alpha=$ .87), conformity ( $\alpha=.80$ ), information exchange ( $\alpha$ $=.81)$, new connections $(\alpha=.79)$, ritual $(\alpha=.80)$, social maintenance ( $\alpha=.75$ ), escapism ( $\alpha=.82$ ), recreation $(\alpha=.83)$, and experimentation $(\alpha=.59)$. In the process of adapting the instrument to the Brazilian Portuguese context, authorization was first requested from the authors of the original version of the SMM-S (Orchard et al., 2014). Once the permission was granted, the items were translated by two language specialists, and then reviewed by a team of translators in both languages (the authors of this article). Subsequently, to guarantee the semantic validity of the instrument, a pilot study was conducted with a non-probability sample of adult users of online social networks (at least ten) who answered the instrument considering a set of criteria (duration, response, understanding the adequacy of the items). After reviewing the structure of the items, the SMM-S was studied with a general population.

\section{Instruments}

The participants answered the online survey with a) A sociodemographic questionnaire (age, gender, marital status, education, income, region of Brazil, favorite online social network). b) The Portuguese version of the SMM-S adapted to the Brazilian context. c) The Satisfaction with Life Scale (Zanon et al., 2014), which assesses respondents' current general satisfaction with life. It consists of five (5) questions (for example: "My life is close to my ideal»,) which were evaluated using a seven-point Likert scale $(1=I$ strongly disagree to $7=I$ strongly agree). The measure has good internal consistency ( $\alpha=.87$ ), with its validity being examined through the CFA and invariance tests. d) The Reduced Personality Markers Scale (Hauck et al., 2012), which assesses the personality based on the Big Five personality model. It is made up of 25 items, which are answered with a five-point Likert scale ranging from 1 = Strongly disagree to 5 = Strongly agree. The scale is divided into five factors; namely, extroversion ( $\alpha=.74)$, socialization $(\alpha=.80)$, conscientiousness ( $\alpha=.76)$, neuroticism ( $\alpha=.55$ ), and openness to experience $(\alpha=.57)$, with each construct being measured by five items.

\section{Data Collection Procedures}

Data collection was conducted online, from July to August 2019, via Google Forms. The invitation to participate in the research was made in person, by e-mail, and through online social networks, considering the study inclusion criteria. It is noteworthy to mention that a downloadable version of the Free and Informed Consent Term was available at the first section of the Google Forms. The signature was associated with agreeing the question «Do you accept to take part in this research?» The average response time was 15 minutes.

\section{Data Analysis}

First, the database was inspected, and missing cases and discrepant responses were adequately treated. Then, sequentially, data were analyzed by CFA procedures using the Mplus software (Muthén \& Muthén, 2012) to observe the adequacy of the internal structure compared to the British version. The 
analytical process was estimated using the weighted least squares mean and variance adjusted (WLSMV), recommended for ordinal data. The fit indices used to examine the adequacy of the models were: chisquare test, where the ratio between chi-square and degrees of freedom $\left(\mathrm{x}^{2} / \mathrm{df}\right)$ considered values below 5; comparative fit index (CFI) and Tucker-Lewis index (TLI), both of which considered values above .90; and root mean square error of approximation (RMSEA), which considered values below .08 (Brown, 2014; Marôco, 2010; Schweizer, 2010).

Due to the results of the CFA, an EFA was performed using the FACTOR program (Ferrando \& Lorenzo-Seva, 2014). A parallel analysis based on polychoric correlations was used to identify the best internal structure (Freires et al., 2018). From the ordinal nature of the data collected, the EFA was carried out using the unweighted least squares (ULS) estimator with promin rotation (Lloret-Segura et al., 2014). The internal consistency of the resulting factors was determined by Cronbach's alpha and McDonald's omega (Trizano-Hermosilla \& Alvarado, 2016) using the $\mathrm{R}$ software (version 4.0.0). Multiple regression analyses were performed to evidence aspects of incremental validity (Brown, 2014), by means of life satisfaction, personality, and reasons for using social media as part of the model.

\section{Results}

\section{Step 1}

Through the CFA procedure, the original structure of the ten-factor SMM-S (Orchard et al., 2014) was tested. From the analyses performed with the Mplus software, it was observed that not all the fit indices showed fully fair values. Therefore, a new model with suggestions for modification indices was tested (F1: e15-e20; F2: e4-e35; F3: e19-e29; F4: e31-e32; F6: e9-e12; F7: e23-e25), thus presenting a slight change in the quality of the fit indices. Table 1 shows the fit indices of all models tested through the CFA.

Table 1

Fit indices of the verified models

\begin{tabular}{cccccc}
\hline Models & $\chi^{2} / \mathrm{df}$ & CFI & TLI & RMSEA & $90 \%$ CI \\
\hline${\text { Model } 1^{\mathrm{a}}}$ & 4.37 & .86 & .84 & .07 & $.07-.07$ \\
${\text { Model } 2^{\mathrm{b}}}^{4}$ & 4.11 & .87 & .85 & .07 & $.06-.07$ \\
\hline
\end{tabular}

Note: ${ }^{\text {a }}$ Model without suggestions for modification indices; ${ }^{\mathrm{b}}$ Model with suggestions for modification indices.

Concerning models one and two, it was observed that the internal structure of the SMM-S in the Brazilian context presented indices that could be questioned due to CFI and TLI indicators below .90.

Based on these results, a second exploratory research of the dimensional structure was conducted using the recommendations of Hauck (2019), mentioned in studies of instrument adaptation from other cultures with inadequate fits. The results are presented in the second part of the study, as detailed below.

\section{Step 2 Results}

Regarding the data adjustment using the factor analysis procedure, the Kaiser-Meyer-Olkin (KMO) and Bartlett's test of sphericity indices were significant $\left[\mathrm{KMO}=.80\right.$; Bartlett, $\chi^{2}(325)=4013.8$; $p<.001]$. A parallel analysis led to the decision of 
using a factorial structure based on the polychoric correlations matrix, which suggested the retention of four factors, as opposed to the original scale that was structured with ten dimensions. A four-factor model with the respective factorial loads of the items was identified in a new analysis using the ULS estimator with promin rotation. The scale's factorial structure is shown in Table 2 and the adjustment indicators were: $\mathrm{x}^{2} / \mathrm{df}=1.5$; CFI $=.99$; GFI $=.98$; AGFI $=.96$; $\mathrm{NNFI}=.98 ; \mathrm{RMSEA}=.04[.01-.05]$.

Table 2

SMM-S factors and items with factorial loadings suggested by the EFA

\begin{tabular}{|c|c|c|c|c|}
\hline Items & Factor 1 & Factor 2 & Factor 3 & Factor 4 \\
\hline $\begin{array}{l}\text { 1. Porque permite que eu me expresse de maneira livre [Because } \\
\text { it allows me to express myself freely]. }\end{array}$ & .80 & -.40 & -.15 & .02 \\
\hline $\begin{array}{l}\text { 2. Para me comunicar com pessoas que eu não conheço [To } \\
\text { communicate with people I do not know]. }\end{array}$ & .65 & -.16 & .21 & -.08 \\
\hline $\begin{array}{l}\text { 3. Porque é o meu tipo favorito de comunicação [Because it is } \\
\text { my favourite type of communication]. }\end{array}$ & .51 & .01 & .14 & .08 \\
\hline $\begin{array}{l}\text { 4. Porque me permite pensar sobre o que quero dizer [Because } \\
\text { it allows me to think about what I want to say]. }\end{array}$ & .64 & .01 & .14 & .07 \\
\hline $\begin{array}{l}\text { 5. Para me comunicar com meus amigos online (ex.: aqueles que } \\
\text { eu conheço virtualmente. mas não pessoalmente) [To } \\
\text { communicate with my online friends (i.e. those who you } \\
\text { know online but have not met in real life)]. }\end{array}$ & .58 & -.11 & .13 & -.01 \\
\hline $\begin{array}{l}\text { 6. Para encontrar um parceiro(a) na qual eu possa me envolver } \\
\text { romanticamente [To find a potential partner/to date]. }\end{array}$ & .38 & .14 & .28 & -.14 \\
\hline $\begin{array}{l}\text { 7. Porque me permite dizer o que eu quiser [Because it allows } \\
\text { me to say what I want]. }\end{array}$ & .78 & .00 & .03 & -.08 \\
\hline 8. Para obter conselhos [To ask for/gain advice]. & .49 & .07 & .17 & .4 \\
\hline 9. Para obter informações [To get information from others]. & .35 & .15 & -.24 & .24 \\
\hline $\begin{array}{l}\text { 10. Porque permite dar voz às minhas opiniões [Because it allows } \\
\text { me to voice my opinions]. }\end{array}$ & .83 & -.07 & -.07 & .03 \\
\hline $\begin{array}{l}\text { 11. Porque permite me comunicar sob menos pressão [Because } \\
\text { it lets me communicate with less pressure]. }\end{array}$ & .68 & .04 & .13 & .00 \\
\hline 12. Porque é emocionante [Because it’s exciting]. & .58 & .14 & -.09 & .11 \\
\hline 13. Para dar conselhos [To give advice]. & .64 & -.12 & .10 & .08 \\
\hline $\begin{array}{l}\text { 14. Para que eu possa fazer novos amigos [So that I can make } \\
\text { new friends]. }\end{array}$ & .76 & -.08 & -.10 & .00 \\
\hline $\begin{array}{l}\text { 15. Porque é uma boa distração com relação às outras coisas } \\
\text { [Because it's a good distraction from other things]. }\end{array}$ & .05 & .55 & -.19 & .04 \\
\hline $\begin{array}{l}\text { 16. Porque me dá algo para fazer [Because it gives me something } \\
\text { to do]. }\end{array}$ & .11 & .69 & .01 & -.07 \\
\hline 17. Porque me ajuda a relaxar [Because it helps me to relax]. & .20 & .58 & -.40 & .18 \\
\hline $\begin{array}{l}\text { 18. Porque naquele momento eu não tenho nada melhor para } \\
\text { fazer [If I have nothing better to do at the time]. }\end{array}$ & -.19 & .71 & -.03 & -.08 \\
\hline 19. Porque se tornou um hábito [Because it's become a habit]. & -.18 & .68 & .17 & .18 \\
\hline 20. Para manter uma rotina diária [To maintain a daily routine]. & -.00 & .51 & .28 & .08 \\
\hline
\end{tabular}




\begin{tabular}{|c|c|c|c|c|}
\hline Items & Factor 1 & Factor 2 & Factor 3 & Factor 4 \\
\hline 21. Para me manter ocupado(a) [To keep myself occupied]. & .03 & .73 & .14 & -.18 \\
\hline 22. Para me livrar do tédio [To cure my boredom]. & .00 & .83 & .01 & -.15 \\
\hline $\begin{array}{l}\text { 23. Porque ajuda a passar o tempo [Because it passes the time } \\
\text { away]. }\end{array}$ & -.10 & .92 & -.10 & -.02 \\
\hline 24. Para me entreter [To entertain myself]. & -.00 & .85 & -.18 & .06 \\
\hline $\begin{array}{l}\text { 25. Para esquecer das responsabilidades na minha vida [To forget } \\
\text { about responsibilities in my life]. }\end{array}$ & .03 & .60 & .21 & -.18 \\
\hline $\begin{array}{l}\text { 26. Porque faz parte da minha rotina na internet [Because it has } \\
\text { become part of my Internet routine]. }\end{array}$ & .03 & .46 & .25 & .27 \\
\hline 27. Para escapar da realidade [To escape reality]. & .06 & .56 & .27 & -.25 \\
\hline $\begin{array}{l}\text { 28. Porque é algo a se fazer [Because it seems to be the thing to } \\
\text { do]. }\end{array}$ & -.03 & .63 & .18 & .12 \\
\hline 29. Porque é divertido [Because it's fun to use]. & .38 & .43 & -.36 & .27 \\
\hline 30. Para ser como as outras pessoas [To be like others]. & .00 & .28 & .45 & -.06 \\
\hline $\begin{array}{l}\text { 31. Porque eu posso mentir e ninguém irá saber [Because I can } \\
\text { lie and no one will know]. }\end{array}$ & .30 & .16 & .50 & -.39 \\
\hline 32. Porque eu tenho que usar [Because I have to]. & -.07 & -.25 & .70 & .22 \\
\hline $\begin{array}{l}\text { 33. Porque todo mundo também usa [Because everyone else } \\
\text { does]. }\end{array}$ & -.24 & .37 & .66 & .20 \\
\hline $\begin{array}{l}\text { 34. Porque eu posso fingir ser outra pessoa [Because I can } \\
\text { pretend to be someone else]. }\end{array}$ & .38 & .09 & .48 & -.46 \\
\hline $\begin{array}{l}\text { 35. Porque as outras pessoas esperam que eu use [Because } \\
\text { other people expect me to use it]. }\end{array}$ & -.03 & .03 & .71 & .25 \\
\hline 36. Para manter contato social [To maintain social contact]. & .08 & .09 & .18 & .60 \\
\hline $\begin{array}{l}\text { 37. Para manter contato com outras pessoas [To keep in touch } \\
\text { with people]. }\end{array}$ & .23 & -.02 & .11 & .65 \\
\hline $\begin{array}{l}\text { 38. Para me comunicar com as pessoas que eu conheço de } \\
\text { maneira offline (ex.: família e amigos que eu conheço na vida } \\
\text { real) [To communicate with those I know offline (i.e. family } \\
\text { and friends you know in real life)]. }\end{array}$ & -.02 & -.02 & .12 & .69 \\
\hline $\begin{array}{l}\text { 39. Para me comunicar com parentes e amigos distantes [To } \\
\text { communicate with distant relatives and friends]. }\end{array}$ & .01 & -.09 & -.00 & .75 \\
\hline $\begin{array}{l}\text { 40. Porque é conveniente para as minhas necessidades [Because } \\
\text { it's convenient for my needs]. }\end{array}$ & .19 & -.08 & .30 & .41 \\
\hline Number of items per factor & 14 & 15 & 6 & 5 \\
\hline Variance & $32 \%$ & $10 \%$ & $7 \%$ & $6 \%$ \\
\hline Alpha coefficient & .86 & .88 & .64 & .78 \\
\hline Omega coefficient & .86 & .89 & .68 & .79 \\
\hline
\end{tabular}


The first dimension was formed by the combination of the factors «new connections,» «freedom of expression,» «ritual,» «recreation,» and «information exchange,» and named in the Brazilian version as Freedom in Social Networks (Liberdade em Redes Sociais - LRS). The factor was based on 14 items and explained 32\% of the data variance. In general, it assessed aspects related to the possibility of expressing oneself freely through online social networks, using them as a source of information, leisure, and a different way of making new contacts. Regarding the dimension's precision, the factor obtained Cronbach's alpha and McDonald's omega coefficients of .86 .

The second dimension brought together the factors «procrastination» and «escapism,» which in turn is composed of the items «ritual,» «freedom of expression,» and «conformity», and was named Routine in Social Networks (Rotina em Redes Sociais - RRS). The final version of the factor had 15 items and explained $10 \%$ of the data variance. The factor evaluated aspects related to the use of online social networks as part of a daily routine, including entertainment, relaxation, and use of idle time. As for consistency, Cronbach's alpha and McDonald's omega coefficients were .88 and .89 , respectively.

The third dimension, labeled as Identity in Social Networks (Identidade em Redes Sociais - IRS), added items from the "conformity» and «experimentation» factors of the original model. Consisting of six items, it explained $7 \%$ of the data variance. The dimension assessed issues related to the users' identity when entering the online environment through social networks, such as their adaptation and experimentation in different ways of behaving in this context. Concerning precision, the factor presented a Cronbach's alpha coefficient of .64 and a McDonald's omega coefficient of .68.

The last and fourth factor was formed by the dimension «social maintenance» and only one item from «information exchange.» It kept its original name, Social Maintenance (Manutenção Social $M S$ ), and presented five items that explained $6 \%$ of the data variance. In general, it evaluated aspects related to online social networks as a tool to keep in touch with people from interpersonal relationships that already existed. The internal consistency had a Cronbach's alpha coefficient of .78 and a McDonald's omega coefficient of .79.

\section{Incremental Evidence of Validity}

With psychometric indicators being more adequate in the four-dimension model (Freedom in Social Networks, Routine in Social Networks, Identity in Social Networks, and Social Maintenance), two groups of multiple regression analysis (stepwise method) were performed to gather incremental evidence of validity of the SMM-S. The first regression model took life satisfaction as a predictor and all four dimensions of the SMM-S as causative variables. The resulting model explained $14 \%$ of the data variance, with the dimensions Routine in Social Networks $(\beta=-.24 ; p<.001)$ and Identity in Social Networks $(\beta=-.18 ; p<.001)$ being the negative predictors. Thus, Social Maintenance was the only positive predictor $(\beta=.30 ; p<.001)$ of life satisfaction. Freedom in Social Networks was not a significant predictor.

In the second part of the analysis, the predictors were all five dimensions of personality (extroversion, socialization, conscientiousness, neuroticism, and openness to experience), with four dimensions of the SMM-S being the explained variables. The results of the models showed that extroversion was a negative predictor of Routine in Social Networks ( $\beta=-.22$; $p<.001$; explained total of 5\%) and Identity in Social Networks ( $\beta=-.11 ; p<.001$; explained total of $4 \%$ ), and a positive predictor of Social Maintenance $(\beta=$ $.17 ; p<.001$; explained total of $6 \%$ ). The conscientiousness trait was a negative predictor of Identity in Social Networks $(\beta=-.15 ; p<.001$; explained total of $4 \%$ ). Finally, openness to experience was a negative predictor of Social Maintenance 
$(\beta=-.13 ; p<.001$; explained total of $6 \%)$. The traits of neuroticism and socialization were not predictors of any of the SMM-S variables and did not confirm theoretical incremental evidence of motivation to use the Internet.

\section{Discussion}

This article sought to examine the internal and incremental evidence of validity of the SMM-S (Orchard et al., 2014) to assess individual motivations for online social network usage among adults in the Brazilian context. The procedures were divided into two stages: Stage 1 proposed to translate, adapt, and preliminarily evidence the internal structure of the original ten-factor instrument based on a CFA. Stage 2 aimed to examine new structures for the SMM-S through an EFA and incremental aspects of the Brazilian dimensional structure with life satisfaction and personality dimensions. In addition, reliability tests such as Cronbach's alpha and McDonald's omega were performed (Trizano-Hermosilla \& Alvarado, 2016), and good psychometric indicators were observed in the Brazilian Portuguese version of the SMM-S.

From the stage 1 analysis, it was found that not all fit indices proved to be adequate for the original ten-factor instrument, resulting in the model not being recommended for the Brazilian sample. It is important to highlight that the authors, when developing the SMM-S (Orchard et al., 2014), used insufficient factorial procedures, including the PCA, to extract the dimensions of the first version of the instrument. Considering the evidence of validity of a psychological instrument, the PCA is not currently the best procedure because searching for internal evidence of the instrument consists in analyzing the latent construct and not only the correlations of latent variables (Damásio, 2012; Fonseca et al., 2020).

In view of the difficulties to adjust the British model, stage 2 was performed to find an adequate structure using an EFA. Therefore, four factors were extracted: Freedom in Social Networks, Routine in Social Networks, Identity in Social Networks, and Social Maintenance. Considering the Uses and Gratifications Theory (Katz et al., 1974), the fourfactor model remained consistent with the proposal of the theoretical axis of the original study, which describes the motivations for choosing and using online social networks based on individual needs and goals, and influenced by contextual and psychological characteristics. The items combination suggested by the EFA also indicated 40 items in the final version but with a more simplified four-dimensional structure capable of assessing the needs and objectives of online social network usage. Said structure included the following: a) Freedom in Social Networks, which included the possibility of expressing ideas, as well as a source of leisure and interpersonal communication, consistent with studies that address the ease of expression that this kind of online services provide (Orchard et al., 2014), and the expression of opinions and affections (Lemos \& Coelho, 2019). b) Routine in Social Networks, which addressed the entertainment provided in the individual's daily life by online social networks: a topic already observed in studies that aim to understand its influence on human behavior (Cruz, 2020) and the habit of using online social networks in everyday life (Del Duca \& Lima, 2019). c) Identity in Social Networks, which brought questions related to the user's identity when entering the online environment through social networks: a topic observed in other studies that address, in this same context, the impacts that can occur on self-esteem (Retuerto \& Guitiérrez, 2017) and self-concept (Mendes \& Silva, 2017). d) Social Maintenance, which referred to maintaining the individual's contacts from relationship networking: a result also observed in other studies, such as those that approached online romantic relationships (Lemos \& Coelho, 2019; Rodrigues, 2019).

All factors showed suitable fit indices and internal consistency (Cohen et al., 2014; McDonald, 1999). However, it is important to mention that factor 3, Identity in Social Networks, presented internal 
consistency values below .70. Some possibilities can be considered regarding this issue. There is no unanimity about the right values concerning precision, but a common agreement is that .70 works as a cutoff. Although sometimes values between .60 and .70 are also satisfactory (de Souza et al., 2017). In this case, the hypothesis is that this dimension has fewer items compared to the others, thus affecting the internal consistency values (Cortina, 1993; de Souza et al., 2017), but it can be employed in research (Clark \& Watson, 1995; Gouveia et al., 2014).

Regarding the incremental evidence of validity, it appears that with respect to personality, extroversion stands out as a negative predictor of Routine in Social Networks and Identity in Social Networks, and as a positive predictor of Social Maintenance. In line with this, extroversion has already been identified in other studies as an important motivator for the use of online social media (Pimentel et al., 2016). Additionally, it is related to the use of online social networks to maintain or expand interpersonal contacts (Conceição, 2016). Finally, Social Maintenance was the only positive predictor of life satisfaction. In other words, individuals who use online social networks to maintain interpersonal relationships tend to feel more satisfied with life. This result confirms the results of studies indicating that online social networks could increase perceived levels of social support, improve life satisfaction (Heo et al., 2015), and promote developing friendships and romantic relationships (Haack \& Falcke, 2017).

The main limitation of this research was the difficulty in obtaining measures in Portuguese that could provide greater direct convergent and divergent evidence of the motivation construct for social media. Furthermore, the sample consisted of individuals from the southeastern states, which could not completely represent the results of the other Brazilian regions.

\section{Conclusion}

Although there is a difference in the number of dimensions compared to the original scale, it is believed that the instrument shows positive evidence of validity in the Brazilian context and will help future research addressing variables concerning the online context. It is suggested that the time spent and motivations for using online social networks are important elements to be analyzed with the help of the SMM-S in future research. The results will aid in interventions and research that aim at exploring self-knowledge on the use of such services and how much it may help or harm individuals in different settings (e.g., work, school). Thus, the SMM-S can be an essential tool for data collection and subsequent interventions in educational, clinical and social contexts.

\section{Conflict of interest}

The authors declare no conflict of interest regarding moral, economic, labor, and research issues.

\section{Ethical responsibility}

This research was approved by the Ethics Committee of [information omitted to preserve the anonymity of the authors], under CAEE No. [information omitted to preserve the anonymity of the authors], according to Resolution No. 466/2012 and Resolution No. 510/2016 of the Brazilian National Health Council. Participation was conditioned to the consent of the terms indicated before the instruments. In addition, participants were informed about privacy, duration, and possible uncomfortable issues that responses may provoke.

\section{Authorship contribution}

All authors participated in the conception and design of the work, data acquisition, analysis and interpretation of data, writing of the manuscript, and critical review of the manuscript. 


\section{Acknowledgments}

This study was funded by CNPQ (The Brazilian National Council for Scientific and Technological Development), CAPES (Coordination for the Improvement of Higher Education Personnel), and FAPES (Support Foundation to Research and Innovation of Espírito Santo).

\section{References}

Arnoux, P. H., Xu, A., Boyette, N., Mahmud, J., Akkiraju, R., \& Sinha, V. (2017). 25 Tweets to Know You: A New Model to Predict Personality with Social Media. Proceedings of the International AAAI Conference on Web and Social Media, 11(1), 472-475. https:// ojs.aaai.org/index.php/ICWSM/article/view/14963

Azucar, D., Marengo, D., \& Settanni, M. (2018). Predicting the Big 5 Personality Traits from Digital Footprints on Social Media: A Meta-Analysis. Personality and Individual Differences, 124, 150-159. https://doi.org/ 10.1016/j.paid.2017.12.018

Blackwell, D., Leaman, C., Tramposch, R., Osborne, C., \& Liss, M. (2017). Extraversion, Neuroticism, Attachment Style and Fear of Missing out as Predictors of Social Media Use and Addiction. Personality and Individual Differences, 116, 69-72. https://doi.org/10.1016/ j.paid.2017.04.039

Bothe, B., Tóth-Király, I., Zsila, Á., Griffiths, M. D., Demetrovics, Z., \& Orosz, G. (2018). The Development of the Problematic Pornography Consumption Scale (PPCS). The Journal of Sex Research, 55(3), 395-406. https://doi.org/10.1080/00224499.2017.1291798

Bowden-Green, T., Hinds, J., \& Joinson, A. (2021). Understanding Neuroticism and Social Media: A Systematic Review. Personality and Individual Differences, 168, 110344. https://doi.org/10.1016/ j.paid.2020.110344

Boyd, D. M., \& Ellison, N. B. (2007). Social Network Sites: Definition, History, and Scholarship. Journal of Computer Mediated Communication, 13(1), 210-230. http://doi.org/10.1111/j.1083-6101.2007.00393.x

Brazilian Internet Steering Committee. (2019). TIC Domicílios 2018. Pesquisa sobre o Uso das Tecnologias da Informação e Comunicação nos
Domicílios Brasileiros. Brazilian Network Information Center. https://cetic.br/media/docs/publicacoes/2/ 12225320191028-tic_dom_2018_livro_eletronico.pdf

Brown, T. A. (2014). Confirmatory Factor Analysis for Applied Research. The Guilford Press.

Celli, F., Bruni, E., \& Lepri, B. (2014, November). Automatic Personality and Interaction Style Recognition from Facebook Profile Pictures [Poster]. 22. ${ }^{\text {nd }}$ ACM international conference on Multimedia, Orlando, Florida, USA. https://dl.acm.org/citation.cfm?id=2654977

Clark, L. A., \& Watson, D. (1995). Constructing Validity: Basic Issues in Objective Scale Development. Psychological Assessment, 7(3), 309-319. https:// doi.org/10.1037/1040-3590.7.3.309

Cohen, R. J., Swerdlik, M. E., \& Sturman, E. D. (2014). Testagem e Avaliação Psicológica: Introdução a Testes e Medidas (8. ${ }^{\text {th }}$ ed). Mc Graw Hill \& Artmed.

Conceição, E. G. (2016). O Fenômeno Facebook no Brasil. Rede Social ou Dependência Digital? [Master's dissertation, Federal University of Rio de Janeiro]. http://objdig.ufrj.br/52/teses/871444.pdf

Copetti, A. V. S., \& Quiroga, C. V. (2018). A influência da mídia nos transtornos alimentares e na autoimagem em adolescentes. Revista de Psicologia da IMED, 10(2), 161-177. http://doi.org/10.18256/2175-5027.2018.v10 i2.2664

Cortina, J. M. (1993). What is Coefficient Alpha? An examination of theory and applications. Applied Psychology, 78(1), 98-104. https://doi.org/10.1037/00219010.78.1.98

Cruz, M. S. C. (2020). Redes sociais virtuais: percepção, finalidade e a influência no comportamento dos acadêmicos. Brazilian Journal of Development, 6(3), 12433-12446. https://doi.org/10.34117/bjdv6n3-199

Damásio, B. F. (2012). Uso da análise fatorial exploratória em psicologia. Avaliação Psicológica, 11(2), 213-228. http://pepsic.bvsalud.org/scielo.php?script=sci_ arttext\&pid=S1677-04712012000200007\&lng =p t\&tlng $=\mathrm{pt}$

D’Arienzo, M. C., Boursier, V., \& Griffiths, M. D. (2019). Addiction to Social Media and Attachment Styles: A Systematic Literature Review. International Journal of 
Mental Health and Addiction, 17(4), 1094-1118. https:/ /doi.org/10.1007/s11469-019-00082-5

de Souza, A. C., Alexandre, N. M. C., \& Guirardello, E. (2017). Propriedades psicométricas na avaliação de instrumentos: avaliação da confiabilidade e da validade. Epidemiologia e serviços de saúde, 26, 649659. https://doi.org/10.5123/S1679-49742017000300022

Del Duca, R. M., \& Lima, V. H. B. (2019). A influência das mídias na adolescência. Cadernos de Psicologia, 1(1), 555-572. https://seer.cesjf.br/index.php/cadernospsico logia/article/view/2000

Durak, M., \& Senol-Durak, E. (2014). Which Personality Traits are Associated with Cognitions Related to Problematic Internet use? Asian Journal of Social Psychology, 17(3), 206-218. http://doi.org/10.1111/ ajsp.12056

Ferrando, P. J., \& Lorenzo-Seva, U. (2014). El análisis factorial exploratorio de los ítems: algunas consideraciones adicionales. Anales de Psicología, 30(3), 1170-1175. http://doi.org/10.6018/analesps. 30.3.199991

Flach, R. M. D., \& Deslandes, S. F. (2017, julho, agosto). A violência digital nos relacionamentos afetivossexuais. [Full text]. Seminário Internacional Fazendo Gênero 11 \& $13^{\text {th }}$ Women's Worlds Congress, Florianópolis, Santa Catarina, Brasil. http://www.wwc 2017.eventos.dype.com.br/resources/anais/149868 7415_ARQUIVO_(Parasubmetermesmo)24.Midias Digitais-Flach\&Deslandes28.06.2017.pdf

Freires, L. A., Sousa, E. A., Loureto, G. D. L., Monteiro, R. P., \& Gouveia, V. V. (2018). Estresse Acadêmico: Adaptação e evidências psicométricas de uma medida. Psicologia em Pesquisa, 12(3), 22-32. http://doi.org/ 10.24879/2018001200300532

Gouveia, V. V., Pessoa, V. D. S., Coutinho, M. D. L., Barros, I. C. D. S., \& Fonseca, A. A. D. (2014). Escala de Procrastinação Ativa: evidências de validade fatorial e consistência interna. Psico-USF, 19(2), 345-354. https:/ /doi.org/10.1590/1413-82712014019002008

Haack, K. R., \& Falcke, D. (2017). Rel@cionamentos. com: Diferenciando os Relacionamentos Amorosos Mediados e não Mediados pela Internet. Revista Colombiana de Psicología, 26(1), 31-44. http://doi.org/ 10.15446/rcp.v26n1.53241
Hauck, N., Machado, W. D. L., Teixeira, M. A. P., \& Bandeira, D. R. (2012). Evidências de validade de marcadores reduzidos para a avaliação da personalidade no modelo dos Cinco Grandes Fatores. Psicologia: Teoria e Pesquisa, 28(4), 417-423. https://doi.org/10.1590/S010237722012000400007

Hauck, N. (2019). Editorial. Avaliação psicológica, 18(1), 1-4. http://doi.org/10.15689/ap.2019.1801.ed

Heo, J., Chun, S., Lee, S., Lee, K. H., \& Kim, J. (2015). Internet Use and Well-Being in Older Adults. Cyberpsychology, Behavior, and Social Networking, 18(5), 268-272. http://doi.org/10.1089/cyber.2014.0549

Hobbs, M., Owen, S., \& Gerber, L. (2017). Liquid Love? Dating Apps, Sex, Relationships and the Digital Transformation of Intimacy. Journal of Sociology, 53(2), 271-284. https://doi.org/10.1177/1440783316662718

Instituto Brasileiro de Geografia e Estatística. (2019). Pesquisa Nacional por Amostra de Domicílios Contínua: notas técnicas - v. 1.6. Instituto Brasileiro de Geografia e Estatística. https://biblioteca.ibge.gov.br/ visualizacao/livros/liv101674_notas_tecnicas.pdf

Katz, E., Blumler, J. G., \& Gurevitch, M. (1974). Utilization of Mass Communication by the Individual. In J. G. Blumler \& E. Katz (eds.), The Uses of Mass Communications: Current Perspectives on Gratifications Research. Sage.

Kircaburun, K., Alhabash, S., Tosuntas, S. B., \& Griffiths, M. D. (2020). Uses and Gratifications of Problematic Social Media use Among University Students: A Simultaneous Examination of the Big Five of Personality Traits, Social Media Platforms, and Social Media Use Motives. International Journal of Mental Health and Addiction, 18(3), 525-547. https://doi.org/ 10.1007/s11469-018-9940-6

Kumar, K. P. K., \& Geethakumari, G. (2014). Detecting Misinformation in Online Social Networks Using Cognitive Psychology. Human-Centric Computing and Information Sciences, 4(1), 1-22. http://doi.org/ 10.1186/s13673-014-0014-x

Krug, R. D. R., Xavier, A. J., \& d'Orsi, E. (2018). Fatores associados à manutenção do uso da internet, estudo longitudinal EpiFloripa Idoso. Revista de Saúde Pública, 52, 37. https://doi.org/10.11606/S15188787.2018052000216 
Lee, E., Lee, J. A., Moon, J. H., \& Sung, Y. (2015). Pictures Speak Louder than Words: Motivations for Using Instagram. Cyberpsychology, Behavior, and Social Networking, 18(9), 552-556. http://doi.org/10.1089/ cyber.2015.0157

Lloret-Segura, S., Ferreres-Traver, A., Hernández-Baeza, A., \& Tomás-Marco, I. (2014). El análisis factorial exploratorio de los ítems: una guía práctica, revisada y actualizada. Anales de Psicología, 30(3), 1151-1169. http://doi.org/10.6018/analesps.30.3.199361

Macedo, K. T. M. (2016). Linchamentos virtuais: paradoxos nas relações sociais contemporâneas. [Master's dissertation, State University of Campinas]. http://repositorio.unicamp.br/bitstream/REPOSIP/ 321038/1/Mercuri_KarenTank_M.pdf

Mark, G., \& Ganzach, Y. (2014). Personality and Internet usage: A large-scale representative study of young adults. Computers in Human Behavior, 36, 274281. http://doi.org/10.1016/j.chb.2014.03.060

Marôco, J. (2010). Análise de equações estruturais: Fundamentos teóricos, software e aplicações. ReportNumber.

Matias, V. R., \& Matos, R. E. (2013). A geografia das tecnologias da informação e comunicação no Brasil contemporâneo. Caminhos de Geografia, 14(48), 1-13. http://www.seer.ufu.br/index.php/caminhosdegeografia/ article/view/22599

Matos, A. P., Costa, J. J., Pinheiro, M. R., Salvador, M. C., Vale-Dias, M. L., \& Zenha-Rela, M. (2016). Anxiety and Dependence to Media and Technology Use: Media Technology Use and Attitudes, and Personality Variables in Portuguese Adolescents. Journal of Global Academic Institute Education \& Social Sciences, 2(2), 1-21. https://estudogeral.sib.uc.pt/ handle/10316/47156

McDonald, R. P. (1999). Test Theory: A Unified Treatment. Erlbaum.

Mendes, I., \& Silva, I. (2017). Uso Problemático da Internet em Adultos: Que relação com sintomas clínicos? Revista De Estudios E Investigación En Psicología Y Educación, 13, 129-133. https://doi.org/10.17979/ reipe.2017.0.13.2565
Muthén, L. K., \& Muthén, B. O. (2012). Mplus: Statistical Analysis with Latent Variables. User's Guide. Muthén \& Muthén.

Orchard, L. J., Fullwood, C., Galbraith, N., \& Morris, N. (2014). Individual Differences as Predictors of Social Networking. Journal of Computer-Mediated Communication, 19(3), 388-402. http://doi.org/10.1111/ jcc4.12068

Patrício, M. R., \& Gonçalves, V. (2010). Facebook: rede social educativa? [Full text]. Anais do I Encontro Internacional TIC e Educação, Lisboa, Portugal. https:/ /bibliotecadigital.ipb.pt/bitstream/10198/3584/1/118.pdf

Pereira, R., Costa, T. M., De Barros, A. C., Bezerra, M. E., Vasconcelos, N. K., Santos, T. M., \& Pereira, T. (2020). Vício no Insta: propriedades psicométricas da escala Bergen de adição ao Instagram. Avances en Psicología Latinoamericana, 38(3), 136-147. https://doi.org/ 10.12804/revistas.urosario.edu.co/apl/a.8132

Pimentel, C. E., Vilar, R., Cavalcanti, J. G., \& Moura, G. B. (2016). Psicologia da era virtual: estrutura das atitudes frente ao Facebook. Pesquisas e Práticas Psicossociais, 11(2), 310-324. http://seer.ufsj.edu.br/index.php/ revista_ppp/article/view/1749/1236

Puerta-Cortés, D. X., \& Carbonell, X. (2014). The Model of the Big Five Personality Factors and Problematic Internet Use in Colombian Youth. Adicciones, 26(1), 54-61. http://doi.org/10.20882/adicciones.131

Recuero, R. C. (2012). A conversação como apropriação na comunicação mediada pelo computador. Comunicação, cultura de rede e jornalismo, 259-274. ht tp://www.raquelrecuero.com/arquivos / raquelrecuerolivrocasper.pdf

Retuerto, N. G., \& Gutiérrez, A. E. (2017). El apoyo social percibido moderador entre el uso problemático de internet y la sintomatología depresiva en jóvenes adultos. Salud y drogas, 17(1), 53-62. http:// www.redalyc.org/articulo.oa?id=83949782006

Rodrigues, B. B. (2019). Redes sociais online e as novas formas de interação amorosa. [Master's dissertation, São Paulo State University]. http://hdl.handle.net/ 11449/181477

Rosado, J. S., Jaeger, M. E., \& Dias, A. C. G. (2014). Padrões de Uso e Motivos para Envolvimento em Redes Sociais 
Virtuais na Adolescência. Interação em Psicologia, 18(1). http://doi.org/10.5380/psi.v18i1.28029

Samarein, Z. A., Far, N. S, Yekleh, M., Tahmasebi, S., Yaryari, V. R., \& Sandi, L. (2013). Relationship between Personality Traits and Internet Addiction of Students at Kharazmi University. International Journal of Psychology and Behavioral Research, 2(1), 10-17.

Seabra, L., Loureiro, M., Pereira, H., Monteiro, S., Afonso, R., \& Esgalhado, G. (2017). Relationship between Internet Addiction and Self-Esteem: Cross-Cultural Study in Portugal and Brazil. Interacting with Computers, 29(5), 767-778. https://doi.org/10.1093/iwc/ iwx011

Servidio, R. (2014). Exploring the Effects of Demographic Factors, Internet Usage and Personality Traits on Internet Addiction in a Sample of Italian University Students. Computers in Human Behavior, 35, 85-92. http://doi.org/10.1016/j.chb.2014.02.024

Schweizer, K. (2010). Some Guidelines Concerning the Modeling of Traits and abilities in Test Construction. European Journal of Psychological Assessment, 26(1), 1-2. http://doi.org/10.1027/1015-5759/a000001

Trizano-Hermosilla, I., \& Alvarado, J. M. (2016). Best Alternatives to Cronbach's Alpha Reliability in Realistic Conditions: Congeneric and Asymmetrical
Measurements. Frontiers in Psychology, 7, 1-8. https://doi.org/10.3389/fpsyg.2016.00769

Uski, S., \& Lampinen, A. (2016). Social Norms and SelfPresentation on Social Network Sites: Profile Work in Action. New Media \& Society, 18(3), 447-464. http:// doi.org/10.1177/1461444814543164

Wang, J. L., Jackson, L. A., Wang, H. Z., \& Gaskin, J. (2015). Predicting Social Networking Site (SNS) Use: Personality, Attitudes, Motivation and Internet SelfEfficacy. Personality and Individual Differences, 80, 119-124. http://doi.org/10.1016/j.paid.2015.02.016

Wang, J. L., Gaskin, J., Rost, D. H., \& Gentile, D. A. (2018). The Reciprocal Relationship Between Passive Social Networking Site (SNS) Usage and Users' Subjective Well-Being. Social Science Computer Review, 36(5), 511-522. https://doi.org/10.1177/0894439317721981

Zanon, C., Bardagi, M. P., Layous, K., \& Hutz, C. S. (2014). Validation of the Satisfaction with Life Scale to Brazilians: Evidences of Measurement Noninvariance Across Brazil and US. Social Indicators Research, 119(1), 443-453. https://doi.org/10.1007/s11205-0130478-5 


\section{Pâmela Fardin Pedruzzi}

Graduate Program in Psychology, Federal University of Espírito Santo, Brazil.

Ph.D. student in Psychology at the Federal University of Espírito Santo. Master's degree in Psychology from the Federal University of Espírito Santo. Bachelor’ degree in Psychology from the Centro Universitário FAESA.

ORCID: https://orcid.org/0000-0003-0869-8602

Autor corresponsal: pamfardin@hotmail.com

Isabela Medeiros de Almeida

Graduate Program in Psychology, Federal University of Espírito Santo, Brazil.

Ph.D. student in Psychology at the Federal University of Espírito Santo. Master's degree in Psychology from the Federal University of Espírito Santo. Bachelor' degree in Psychology from the Centro Universitário FAESA.

ORCID: https://orcid.org/0000-0003-2377-2364

isabelamedeirosdealmeida@gmail.com

Fabíola Rodrigues Matos

Graduate Program in Psychology, Federal University of Espírito Santo, Brazil.

Ph.D. in Psychology from the Federal University of Espírito Santo. Master's degree and Bachelor' degree in Psychology from the Federal University of Uberlândia.

ORCID: https://orcid.org/0000-0002-2828-2869

fabiolarmatos@yahoo.com.br

Alexsandro Luiz de Andrade

Graduate Program in Psychology, Federal University of Espírito Santo, Brazil.

Psychology professor at the Graduate Program in Psychology at the Federal University of Espírito Santo. Ph.D. in Psychology from the Federal University of Espírito Santo.

ORCID: https://orcid.org/0000-0003-4953-0363

alexsandro.deandrade@yahoo.com 